\title{
Main pig diseases in France according to laboratory statistics
}

\author{
L. RENAULT, A. MARTIN, M. PALISSE, Th. LINDIE, Cl. MAIRE, J. VAISSAIRE
}

Etablissements Sanders, 17. quai de l'Industrie, 91260 Juvisy-sur-Orge

The results are expressed as percentages after examination of I I 59 pigs and viscera, according to the age of the animals (birth, weaning, fattening, reproduction), the clinical criteria and lesions and according to the principal agents (parasites, germs, virus).

The values of these percentages are not absolute, but they allow to determine the relative importance of the main discases, to follow their evolution and to develop a more efficient prevention.

\section{Biochemistry of hlood and electrophoresis of serum proteins : interest for pig pathology}

J. VAISSAIRE, I. RENAUlT, M. PALISSE, Th. LINDER, Cl. MAIRE, J.-P., LABADIE

Établissements Sanders, 17. quai de l'Industrie, 91260 Juvisy-sur-Orge

Study of $\mathrm{I} 600$ sera from pigs between the ages of $\mathrm{I}$ day to 3 years clearly shows the great interest of using blood chemistry and serum protein electrophoresis for controlling health of pig herds. These two techniques which are always used in connection with those of the laboratory, lead to a better diagnosis and to a more specific prognosis on one subject only or on the whole herd. 